\title{
Klippel-Feil Syndrome: A Case Report
}

\section{Klippel-Feil Sendromu: Olgu Sunumu}

\section{Zeliha Fazlıoğulları', @Abdussamet Batur², @Ekrem Solmaz', @Ayşe Gamze Özcan', DMehmet Cengiz Tatar ${ }^{1}$}

'Selcuk University School of Medicine Department of Anatomy, Konya, Turkey

${ }^{2}$ Selcuk University School of Medicine Department of Radiology, Konya, Turkey

\begin{abstract}
Klippel-Feil syndrome is a syndrome that may involve other skeletal and extra-skeletal anomalies as well as fusion of the spine due to the absence of normal segmentation in cervical structures. In our case, we aimed to describe this rare syndrome, to show the findings obtained by imaging methods, and to emphasize the importance of directing it to early diagnosis and necessary treatment modalities. A 41-year-old female patient presented to our hospital with neck pain. Using cervical magnetic resonance imaging, we observed a decreased anteroposterior diameter; fusion between the corpora of the 2 nd - 4th cervical spine; and an appearance consistent with fusion between the arches of the same vertebrae in sagittal slices. Cadaver studies and radiology tests were performed to identify the variations and anomalies of the cervical spine. Although computed tomography scanning is more frequently performed for the purpose of evaluating spine, magnetic resonance imaging may be performed to evaluate the adjacent soft tissue structures and the symptoms associated with vertebral pathologies. These imaging modalities are necessary and beneficial for anatomists, radiologists, neurosurgeons, and orthopedists so that they may evaluate the findings, coexisting anomalies, and risk factors of Klippel-Feil syndrome in order to reach appropriate diagnosis, follow-up, and treatment.
\end{abstract}

Keywords: Klippel - Feil syndrome; spine; magnetic resonance imaging

\section{INTRODUCTION}

Klippel-Feil syndrome (KFS) was first described by Maurice Klippel and Andre Feil in 1912 as an anomaly that is characterized by fusion of at least two cervical spine vertebraes. ${ }^{[1]} \mathrm{KFS}$ is a rare congenital anomaly and is slightly more prevalent in women than in men, with an incidence of 1 in $42,000 .^{[2]}$

This syndrome is except phenotypic features such as short neck, generally asymptomatic in pediatric patients, but the symptoms become more distinct in adulthood. KFS may coexist with various skeletal, renal, and cardiovascular
Öz

Klippel-Feil sendromu, servikal yapılarda normal segmentasyonun oluşmamas sonucu vertebraların füzyonu yanı sıra diğer iskelet ve iskelet dışı anomallileri de içerebilen bir sendromdur. Vakamızda nadir görülen bu sendromu tanımlamayı, görüntüleme yöntemleri ile elde edilen bulguları göstermeyi ve erken teşhis ve gerekli tedavi modalitelerine yönlendirmenin önemini belirtmeyi amaçladık. Boyun ağrısı şikâyeti ile hastanemize başvuran 41 yaşındaki kadın hastanın çekilen servikal manyetik rezonans görüntülemesinde sagital kesitlerde 2. - 4. servikal vertebra korpusları arasında füzyon ve anteroposterior çapta azalma ile aynı vertebraların arkusları arasında füzyon ile uyumlu görünüm tespit edildi. Servikal vertebraların varyasyonlarını ve anomalilerini tanımlamak için kadavra çalışmalarından ve radyolojik tetkiklerden faydalanılır. Bilgisayarlı tomografi, vertebraların değerlendirmesinde daha sık kullanılsa da komşu yumuşak doku yapılarının ve vertebrae patolojilerine bağı semptomların değerlendirilmesinde manyetik rezonans görüntüleme kullanılmaktadır. Klippel-feil sendromuna ait bulguların, eşlik eden anomalilerin ve risk faktörlerinin değerlendirilmesi için kullanılan bu görüntüleme yöntemleri uygun tanı, takip ve tedavi için anatomist, radyolog, nöroşirurjist ve ortopedistler açısından gerekli ve faydalıdır.

Anahtar kelimeler: Klippel-Feil sendromu, vertebra, manyetik rezonans görüntüleme

anomalies. ${ }^{[3]}$ Although diagnosis of this syndrome is generally based on radiology tests performed on patients who present with short neck, low hairline at the back of the head, neck pain, and limited range of motion in the neck, it may also be diagnosed incidentally via radiological imaging tests performed for other purposes. ${ }^{[4]}$

Although KFS is mainly sporadic, some KFS types are autosomal dominant or recessive due to an anomaly in the GDF6, MEOX1, GDF3, and MYO18B genes on chromosomes $8,17,12$, and 22 , respectively. ${ }^{[5]}$ 
Physical therapy and surgery may contribute to quality of life in eligible patients. In this case report, we aimed to describe this rare syndrome, show its findings using imaging tests, and demonstrate its clinical importance.

\section{CASE REPORT}

A 41-year-old female patient presented to our hospital with a stiff neck and neck pain. Informed constent of the patient was obtained. Upon cervical magnetic resonance imaging (MRI), we noted a decreased anteroposterior diameter; fusion between the corpora of the $2^{\text {nd }}, 3^{\text {rd }}$, and $4^{\text {th }}$ cervical vertebrae; and an appearance consistent with fusion between the arches of the same vertebrae as well as a minimal diffuse protrusion in the 5th and 6th intervertebral discs in sagittal slices. Structures of the craniovertebral junction and cervical spinal cord were normal. Furthermore, direct radiographs and sagittal slices previously obtained via computed tomography (CT) revealed mild scoliosis, with a curve facing to the right and with fusion between the corpora of the $2^{\text {nd }}, 3^{\text {rd }}$, and $4^{\text {th }}$ cervical vertebrae (Figure 1). These findings were consistent with type 1 (diffuse vertebral fusion in the cervical region) KFS according to Feil's classification. There is no genetic diagnosis or any other accompanying pathology in the patient.

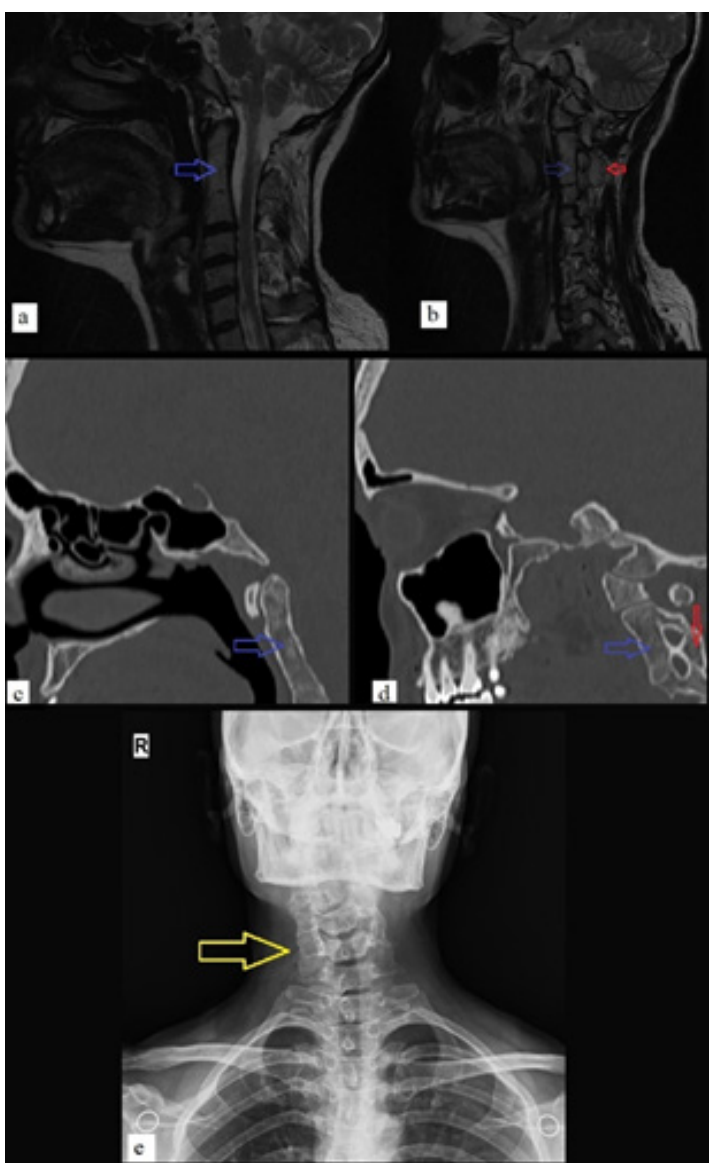

Figure 1. Sagittal slices of the cervical region in T2-weighted MR images (Blue arrow, fusion in the vertebral corpus $(\mathrm{a}, \mathrm{b})$; red arrow, fusion in the vertebral arch (b)). Sagittal slices in CT images (Blue arrow, fusion in the vertebral corpus (c, d); red arrow, fusion in the vertebral arch (d)). Direct anteroposterior radiographs (Yellow arrow, scoliosis (e)).

\section{DISCUSSION}

KFS is a congenital malformation that develops as a result of a defect in the segmentation of cervical somites between gestational weeks three and eight, and genetic factors are involved in its etiology. KFS may originate from mutations or changes in genes involved in the formation of segmentation. [3,5,6] The most common clinical symptoms of the typical triad of a short neck, a low posterior hairline, and a limited range of neck motion owing to the fusion of cervical vertebrae include a stiff neck and neck pain; these symptoms are similar to those presented by the patient described in this report. As of today, the aforementioned triad is not observed in half of all patients with KFS. ${ }^{[1]}$ Although KFS is frequently diagnosed in childhood, it is diagnosed in adulthood in some patients, as it was in our patient. ${ }^{[7]}$

Feil's classification divides KFS into three main types based on radiologic appearance. Type 1 exhibits diffuse vertebral fusion in the cervical region (consistent with our case), type 2 exhibits one or two fusions, and type 3 exhibits additional vertebral fusion in the lumbar region. ${ }^{[8]}$

According to Samartzis classification, KFS is classified as type 1 in the presence of vertebral fusion in one segment of the cervical region, classified as type 2 in the presence of non-contiguous vertebral fusions in multiple segments, and classified as type 3 in the presence of contiguous vertebral fusions in multiple segments based on radiologic evaluation. [9] Our patient had type 3 KFS according to Samartzis classification.

Although the highest extent of fusion has been observed at the $2^{\text {nd }}$ and $3^{\text {rd }}$ cervical vertebrae in some studies, the $4^{\text {th }}$ cervical vertebra was also fused in our patient. ${ }^{[10]}$ The appearance of the corpora of these vertebrae was consistent with that of block vertebrae.

KFS is most frequently accompanied by skeletal anomalies, including kyphosis or scoliosis (60\%), Sprengel deformity $(20 \%)$, torticollis (20\%), and facial asymmetry (20\%). Genitourinary system anomalies (35-65\%), hearing loss (30\%), and congenital heart diseases (5-15\%) are among the most commonly encountered systemic anomalies that coexist with KFS. Renal agenesis is the most commonly observed genitourinary anomaly, and VSD is the most commonly observed cardiac anomaly. ${ }^{[3,9]}$ In patients with KFS, the prevalence of scoliosis is $70 \%$ and that of cervical scoliosis is $53 \%{ }^{[1,9]}$ Our patient also had mild scoliosis with a curve facing to the right.

The first choices of imaging modalities for patients suspected of having KFS should include anteroposterior, lateral, and oblique cervical vertebra radiographs. However, because bone deformities make it difficult to position such patients, overlapping of the mandible, the occipital bone, and the foramen magnum on images may be misleading and may therefore complicate the evaluation of cervical vertebrae. Lateral and odontoid radiography and CT may be necessary when trauma, trauma-related fractures, or subluxation 
are suspected. ${ }^{[11]}$ If a patient has neurologic deficits, MRI is recommended to evaluate the patient's spinal cord. Differential diagnoses of infection, juvenile idiopathic arthritis, and rheumatoid spondylitis with radiologic findings similar to those of KFS should also be considered when vertebral fusion is present. ${ }^{[6]}$

KFS should also be considered in the preliminary diagnosis of adult patients with shoulder and neck pain as well as limited neck movement. Additionally, patients should also be examined and evaluated for coexisting anomalies. KFS can be diagnosed with suitable imaging modalities by considering risk factors, and patients can be provided with appropriate follow-up and treatment.

\section{ETHICAL CONSIDERATIONS}

Informed Consent: Written informed consent was obtained from all participants who participated in this study.

Status of Peer-review: Externally peer-reviewed.

Conflict of Interest Statement: The authors have no conflicts of interest to declare.

Financial Disclosure: The authors declared that this study has received no financial support.

Author Contributions: ZF: designing, evaluation of the data, writing text, $A B$ : image acquisition and analysis, evaluation of the data, ES: designing, evaluation of the data, writing text, AGO: evaluation of the data, writing text, MCT: evaluation of the data, writing text

\section{REFERENCES}

1. Thomsen MN, Schneider $U$, Weber $M$, et al. Scoliosis and congenital anomalies associated with Klippel-Feil syndrome types I-III. Spine. 1997;22(4):396-401.

2. Kaplan KM, Spivak JM, Bendo JA. Embryology of the spine and associated congenital abnormalities. Spine J. 2005;5(5):564-76.

3. Hensinger RN, Lang JE, MacEwen GD. Klippel-Feil syndrome; a constellation of associated anomalies. J Bone Joint Surg Am. 1974;56(6):1246-53.

4. Copley LA, Dormans JP. Cervical spine disorders in infants and children. J Am Acad Orthop Surg. 1998;6(4):204-14.

5. Frikha R. Klippel-Feil syndrome: a review of the literature. Clin Dysmorphol. 2020; 29(1):35-37.

6. Tracy M, Dormans JP, Kusumi K. Klippel-Feil syndrome: clinical features and current understanding of etiology. Clin Orthop Relat Res. 2004;424:18390.

7. Terzi R, Voyvada B, Terzi H, et al. Pelvic renal ectopia accompanying Klippel Feil syndrome diagnosed at a later age. Kocaeli Med J. 2012;1(2):26-30.

8. Gunderson $\mathrm{CH}$, Greenspan RH, Glaser GH, et al. The Klippel-Feil syndrome: genetic and clinical reevaluation of cervical fusion. Medicine (Baltimore). 1967;46(6):491-512.

9. Samartzis D, Herman J, Lubicky JP, et al. Classification of congenitally fused cervical patterns in Klippel-Feil patients: epidemiology and role in the development of cervical spine-related symptoms. Spine. 2006;31(21):E798-E804.

10. Ulmer JL, Elster AD, Ginsberg LE. Klippel-Feil syndrome: $C T$ and MR of acquired and congenital abnormalities of cervical spine and cord. J Comput Assist Tomogr. 1993;17(2):215-24.
11. Hensinger RN. Orthopedic problems of the shoulder and neck. Pediatr Clin North Am. 1986;33(6):1495-509. 